Original Article (short paper)

\title{
Trends in television and computer/videogame use and total screen time in high school students from Caruaru city, Pernambuco, Brazil: A repeated panel study between 2007 and 2012
}

\author{
Luis José Lagos Aros $^{1}$, Antonio Henrique Germano-Soares ${ }^{1}$, Caroline Ramos de Moura Silva ${ }^{1}$, Alison Oliveira da \\ Silva $^{1}$, Rafael Miranda Tassitano ${ }^{2 *}$ \\ ${ }^{1}$ Universidade de Pernambuco, UPE, Recife, PE, Brazil; ${ }^{2}$ Universidade Federal \\ Rural de Pernambuco, UFRPE, Recife, PE, Brazil.
}

\begin{abstract}
Aim: to analyze the pattern and trends of use of screen-based devices and associated factors from two surveys conducted on public high school students in Caruaru-PE. Methods: two representative school-based crosssectional surveys conducted in $2007(\mathrm{n}=600)$ and $2012(\mathrm{n}=715)$ on high school students ( $15-20$ years old). The time of exposure to television (TV) and computer/videogames PC/VG was obtained through a validated questionnaire, and $\geq 3$ hours/day was considered as being excessive exposure. The independent variables were socioeconomic status, school related, and physical activity. Crude and adjusted binary logistic regression were employed to examine the factors associated with screen time. The statistical significance was set at $p<0.05$. Results: There was a significant reduction in TV time on weekdays and total weekly, but no change in the prevalence of excessive exposure. The proportion of exposure to $\mathrm{PC} / \mathrm{VG}$ of $\geq 3$ hours/day increased $182.5 \%$ on weekdays and $69.5 \%$ on weekends ( $\mathrm{p}<0.05$ ). In 2007, being physically active was the only protection factor for excessive exposure to total screen time. In 2012, girls presented less chance of excessive exposure to all screen-based devices and total screen time. Other protective factors were studying at night and being physically active (PC/VG time), while residing in an urban area [OR 5.03(2.77-7.41)] and having higher family income [OR 1.55(1.04-2.30)] were risk factors. Conclusion: Significant and important changes in the time trends and pattern of use PC/VG were observed during the interval of 5 years. This rapid increase could be associated with increased family income and improved access to these devices, driven by technological developments.
\end{abstract}

Keywords: screen time. sedentary lifestyle. risk factors. students

\section{Introduction}

There has been rapid and progressive growth in research examining screen time as an indicator of sedentary behavior in children and adolescents, especially concerning excessive exposure to screen-based devices (television, TV; videogames, VG; and computers, PC). Systematic reviews indicate that sedentary behavior is associated with negative health outcomes (i.e., physical function, obesity, academic achievement, and psychosocial parameters) in this subgroup ${ }^{1-2}$. Therefore, changes in lifestyle have been encouraged in childhood and adolescence ${ }^{3,4}$.

Studies on trends of exposure to screen time in adolescents have been conducted, mainly in high-income countries ${ }^{5-7}$. Data from the Youth Risk Behavior Surveillance showed that exposure to TV of least 2 hours/day reduced from 1999 to $2007^{5}$. Conversely, Nelson et al. ${ }^{6}$ demonstrated an increase in exposure to PCs between 1999 and 2004. Moreover, a previous study conducted in seven European countries ${ }^{7}$ showed that the proportion of exposure to TV for at least 4 hours/day decreased from 1985/86 and 1997/98 in Norway, Scotland, and Wales, while it increased in Hungary, Austria, and Finland. These results indicate that trends of exposure to screen-based devices vary across countries.

In Brazil, changes in the patterns of exposure to screen time in adolescents have been addressed in few studies ${ }^{8-9}$. Silva et al. ${ }^{8}$ found that exposure to TV reduced, while exposure to $\mathrm{PC} /$ VG increased from 2001 to 2011 in the state of Santa Catarina, in southern Brazil. Lopes et al. ${ }^{9}$ reported in literature that these changes were similar between boys and girls, but were stronger on weekend days. However, since sociodemographic factors are associated with different changes in patterns of TV or PC/VG use $^{8}$, and access to electronic devices varies between states and cities (i.e., due to socioeconomic inequalities ${ }^{10}$ ), such results cannot be extrapolated to other regions of Brazil (e.g., northern). In fact, the PNAD report on access to internet, television, and cell phone use revealed marked changes in access to technology, consumption habits, and interactivity of Brazilians with screen devices, indicating differences between these regions and states ${ }^{11}$.

Thus, the aim of this study was to analyze the pattern and trends of use of screen devices and associated factors from two surveys (2007 and 2012) conducted on public high school students of Caruaru-PE. 


\section{Methods}

\section{Design}

This study compared data from two epidemiological, crosssectional, school-based surveys entitled "Lifestyle and health risk behaviors in adolescents: a temporal trend from 2007 to 2012". The first data collection was carried out in October 2007 and the second in October 2012. The Ethics Committee on Research with Human Beings of the Associação Caruaruense de Educação Superior approved the study procedures for both surveys (CAAE: 07296612.3.0000.5203).

The population comprised students of both genders $(15-20$ years) from public high schools of Caruaru-PE. The municipality is geographically divided into three regions (North, Center, and South). According to data from the Department of Education and Culture of the State of Pernambuco, during the two surveys, there were 15 public high schools. The population of students in 2007 was 8,833 and in 2012 the total number of students enrolled was 9,405. In both surveys, the same parameters were used for the sample calculation, sampling process, instruments, and data collection.

\section{Planning and sample selection}

In both surveys, the sample size was calculated based on information from the school census, and the following parameters were also considered: 95\% confidence interval; maximum tolerable error of $5 \%$; and sampling effect of 1.5 . The prevalence was estimated at $50 \%$ since multiple outcomes were considered. Thus, in the 2007 survey, the estimated sample was 541 students. Due to possible losses and refusals, the calculated sample was multiplied by 1.2 , totaling 649 students. In the 2012 survey, the estimated sample was 543 adolescents. The same procedure of multiplying the sample by 1.2 was adopted, totaling 652 students.

The sample selection was by conglomerate in two stages. In the first stage, the schools were considered as the sample unit. The selection of schools was random and the following stratification criteria were considered: (a) school and student density in each micro region of the municipality; and (b) school size (small: less than 200 students, average: 200 to 499 students, and large: 500 students or more). In the second stage, the proportion of students enrolled per class was considered, respecting the proportion of students enrolled in schools and regions. For the only school classified as small, it was guaranteed that at least one class would be selected as part of the sample. Considering the average number of students enrolled per class, 16 classrooms from eight schools were randomly selected in 2007 and 19 classrooms from eight schools in 2012. Data collections always took place in October and the following procedures were adopted: a) prior contact with the principal of each school to send the terms of consent and to schedule visits; B) training of researchers for field procedures.

The questionnaire was applied in the classroom with all the students of the groups selected on the day of the visit. At the beginning of the study, the researcher communicated the objectives of the study, informing students that all information would be kept confidential, would not affect their academic performance, and would only be used for research purposes. In addition, students were instructed not to identify themselves in the questionnaire. In the case of students over 18 years of age, the free and informed consent form was signed, while for students under 18 years of age, parental consent was requested. In addition, prior to carrying out the fieldwork, the directors of all the schools were consulted and only with their consent were data collected.

\section{Instrument}

Data were collected through the questionnaire entitled "Risk Behaviors in adolescents from Santa Catarina (COMCAP)", which has been previously validated and used on students from the Brazilian public school system ${ }^{8,9,12}$. The questionnaire was also applied in a pilot study with adolescents from Caruaru and achieved moderate to high reproducibility measures $(0.62$ $-1.00)$. For the present study, we used information from the socio-demographic (gender, age, place of residence with family, marital status, children, and monthly family income); school related (study shift and high school grade) and behavioral sections (physical activity and sedentary behavior). The time of moderate to vigorous physical activity was measured in minutes during a typical week and all dimensions of physical activity were taken into account. Adolescents who reported $\geq 300$ minutes / week were considered as being physically active.

Information related to the different types of screen time, considered as outcomes, was collected (TV, PC, and VG) and time spent on weekdays, weekends, and weekly total. To obtain this information the following questions were asked: "During the days of the week how many hours a day do you watch television?"; "During the weekend, how many hours a day do you watch television?"; "During the days of the week, how many hours a day do you use a computer or videogame?"; "During the weekend, how many hours a day do you use a computer or videogame?" The answers were given considering the total time, in hours per day, for each of the questions. For estimation of total screen time during the week, a time weighting was performed on weekdays ( 5 days) and on weekend days ( 2 days).

\section{Data analysis}

The data were tabulated in the EpiData program (version 3.1) and analyzed in SPSS software (version 15.0). The mean and standard deviation values (numerical data) and relative frequencies (categorical data) were used for the descriptive statistics. The average time of screen exposure to the different electronic devices (mean time during the week, weekend, and total weekly time) between the 2007 and 2012 surveys was compared using the Mann-Whitney test, while the Chi-square test was used to compare the proportions. The cut-off point of $\geq$ 3 hours/day was considered as indicative of excessive exposure for all indicators of sedentary behavior. Six crude and adjusted binary logistic regressions were performed considering TV, 
PC/VG, and total screen time in both periods. The proportion of adolescents with excessive exposure to the different screen devices was adopted as the dependent variable, whereas the independent variables were sex (male, female), age (15-17 years, 18-20 years), marital status (single, other), place of residence (urban, rural), monthly family income (up to R\$ $1,000.00$ and $\mathrm{R} \$ 1,001.00$ or more), high school grade (1st, 2nd, and $3^{\text {rd }}$ year), study shift (morning and at night), and physical activity (inactive, active). For all analyses, $\mathrm{p}<0.05$ was considered as statistically significant.

\section{Results}

Table 1 summarizes the general characteristics of the samples between surveys. No differences were observed in relation to the sociodemographic and school-related characteristics. In both surveys, the majority of students was female, aged between 16 and 18 years old, single, urban residents, living with family, and studied during the evening period. The proportion of students with monthly family income $\geq \mathrm{R} \$ 1,001$. 00 increased from 2007 to $2012(\mathrm{p}<0.01)$.

Table 1. Sociodemographic, economic, and school-related distribution of high school students in the public school network of Caruaru, PE, Brazil $-2007(n=600)$ and $2012(n=715)$.

\begin{tabular}{|c|c|c|c|c|c|}
\hline \multirow{2}{*}{ Variables } & \multicolumn{2}{|c|}{2007} & \multicolumn{2}{|c|}{2012} & \multirow{2}{*}{ F } \\
\hline & $\%$ & $\mathbf{n}$ & $\%$ & $\mathbf{N}$ & \\
\hline \multicolumn{6}{|l|}{ Gender } \\
\hline Boys & 37.5 & 225 & 39.3 & 281 & \multirow{2}{*}{0.50} \\
\hline Girls & 62.5 & 375 & 60.7 & 434 & \\
\hline \multicolumn{6}{|l|}{ Age } \\
\hline 15 & 9.5 & 57 & 9.1 & 65 & \multirow{6}{*}{0.30} \\
\hline 16 & 21.2 & 127 & 21.3 & 152 & \\
\hline 17 & 24.5 & 147 & 28.1 & 201 & \\
\hline 18 & 19.5 & 117 & 18.0 & 129 & \\
\hline 19 & 12.3 & 74 & 14.4 & 103 & \\
\hline 20 & 13.0 & 78 & 9.1 & 65 & \\
\hline \multicolumn{6}{|l|}{ Marital Status } \\
\hline Single & 95.2 & 572 & 95.2 & 681 & \multirow{3}{*}{0.80} \\
\hline Married & 2.2 & 13 & 1.9 & 13 & \\
\hline Other & 2.6 & 15 & 2.9 & 21 & \\
\hline \multicolumn{6}{|l|}{ Place of residence } \\
\hline Rural & 10.7 & 64 & 8.7 & 62 & \multirow{2}{*}{0.34} \\
\hline Urban & 89.3 & 536 & 91.3 & 653 & \\
\hline \multicolumn{6}{|l|}{ Live with family } \\
\hline Yes & 95.9 & 575 & 93.3 & 667 & \multirow{2}{*}{0.06} \\
\hline No & 4.1 & 25 & 6.7 & 48 & \\
\hline \multicolumn{6}{|l|}{ Monthly household income } \\
\hline Up to $\mathrm{R} \$ 1.000,00$ & 71.8 & 231 & 66.4 & 475 & \multirow{2}{*}{0.01} \\
\hline $\mathrm{R} \$ 1.001,00$ or more & 28.2 & 169 & 33.6 & 240 & \\
\hline \multicolumn{6}{|l|}{ High school year } \\
\hline $1 \mathrm{st}$ & 47.3 & 284 & 44.5 & 318 & \multirow{3}{*}{0.43} \\
\hline $2^{\text {nd }}$ & 31.5 & 189 & 31.9 & 228 & \\
\hline $3^{\text {rd }}$ & 21.2 & 127 & 23.6 & 169 & \\
\hline \multicolumn{6}{|l|}{ Study Shift } \\
\hline Morning & 44.7 & 268 & 49.8 & 356 & \multirow{2}{*}{0.08} \\
\hline At night & 55.3 & 332 & 50.2 & 359 & \\
\hline
\end{tabular}

Table 2 shows the comparisons of the average time of exposure to $\mathrm{TV}, \mathrm{VG} / \mathrm{PC}$, and total screen time on weekdays, weekend days, and total weekly time from the 2007 and 2012 surveys. The time of exposure to TV did not change on weekend days $(\mathrm{p}=0.10)$, but reduced on weekdays and weekly from 2007 to $2012(\mathrm{p}<0.01)$. The time of exposure to PCs and VGs, as well as the total screen time, increased significantly on weekdays, on weekend days, and total weekly time ( $\mathrm{p}<0.01$ for all comparisons). 
Table 2. Mean and standard deviation of the time spent on screen electronic devices (in hours) during the weekdays, weekends, and weekly total of high school students of the public school network of Caruaru, PE, Brazil - 2007 and 2012.

\begin{tabular}{|c|c|c|c|}
\hline Variables & $\begin{array}{c}2007 \\
(n=600)\end{array}$ & $\begin{array}{c}2012 \\
(n=715)\end{array}$ & $\mathbf{p}^{*}$ \\
\hline & Mean \pm & Mean \pm & \\
\hline TV (weekdays) & $2.45 \pm 2.10$ & $2.09 \pm 1.90$ & $<0.01$ \\
\hline TV (weekend days) & $3.91 \pm 3.12$ & $3.98 \pm 2.92$ & 0.10 \\
\hline TV (weekly) & $2.87 \pm 2.04$ & $2.62 \pm 1.81$ & 0.01 \\
\hline PC/VG (week days) & $1.19 \pm 1.39$ & $2.00 \pm 2.39$ & $<0.01$ \\
\hline PC/VG (weekend days) & $2.35 \pm 2.18$ & $3.81 \pm 3.30$ & $<0.01$ \\
\hline PC/VG (weekly) & $1.52 \pm 1.14$ & $2.51 \pm 2.34$ & $<0.01$ \\
\hline Total screen time (week days) & $5.11 \pm 3.42$ & $5.98 \pm 4.01$ & $<0.01$ \\
\hline Total screen time (weekend days) & $6.21 \pm 4.17$ & $7.78 \pm 4.98$ & $<0.01$ \\
\hline Total screen time (weekly) & $4.40 \pm 2.60$ & $5.14 \pm 3.38$ & $<0.01$ \\
\hline
\end{tabular}

Note: $\mathrm{TV}=$ Television; $\mathrm{PC}=$ Computer; $\mathrm{VG}=$ Videogame; $\mathrm{SD}-$ standard deviation. $*$ Mann-Whitney $\mathrm{U}$ test.

Figure 1 presents the comparisons of the proportion of students who presented excessive exposure to the different screen-based devices from 2007 to 2012. The proportion of adolescents exposed to $\geq 3$ hours/day of PC/VG increased $182.5 \%$ on weekdays and $69.5 \%$ on weekend days from 2007 to 2012 $(\mathrm{p}<0.05)$. On the other hand, no changes were observed for exposure to TV and total screen time between surveys (Figure 1).

Figure 1. Prevalence of exposure ( $\geq 3$ hours / day) to the different screen-based devices and total screen time, considering weekdays and weekend days in high school students of the public school network of Caruaru, PE, 2007 and 2012.

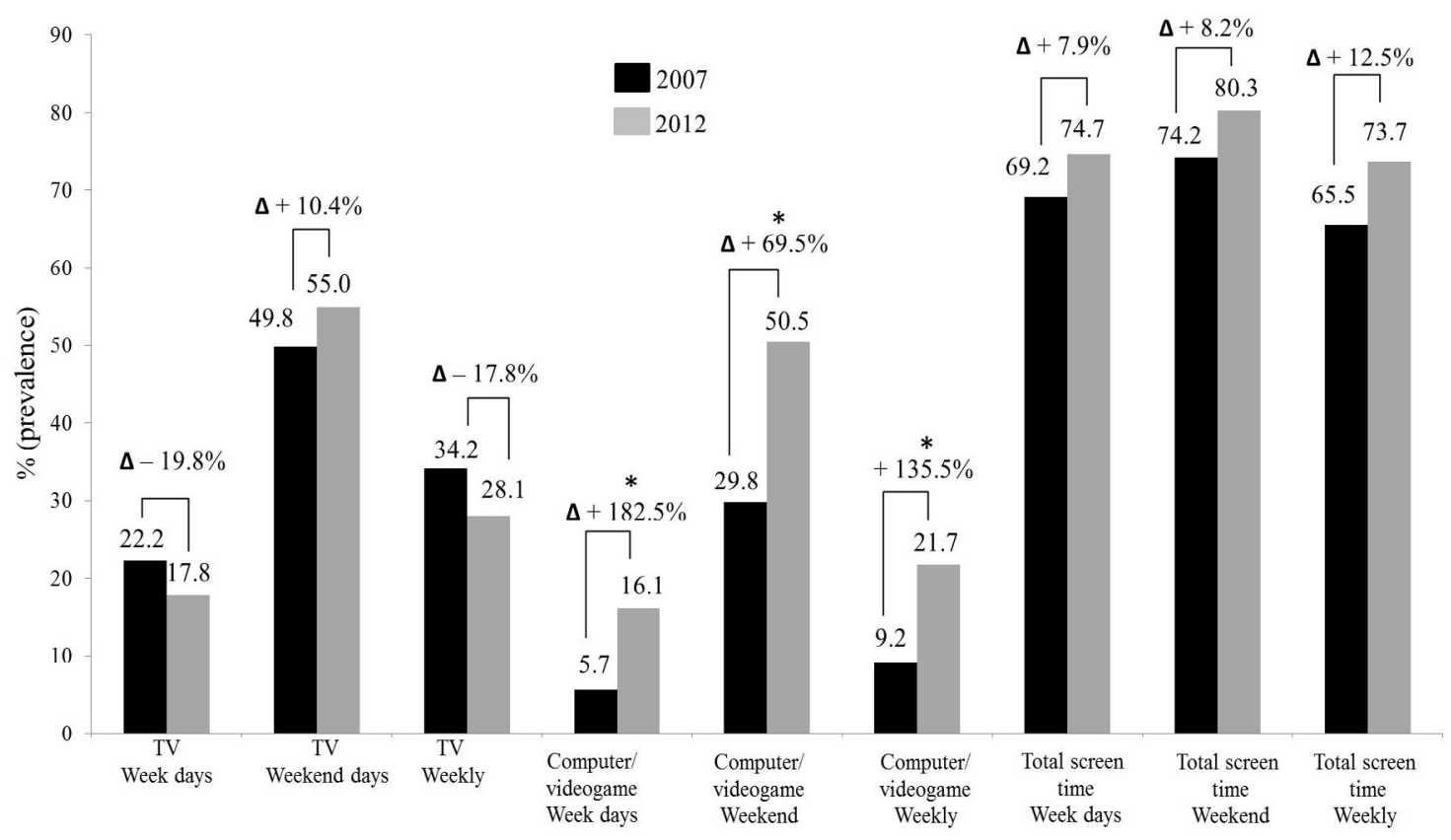

A difference was observed between TV exposure time on weekdays and weekend days. During the week, the majority of adolescents reported $\leq 2$ hours/day of TV exposure, whereas on weekends a large proportion reported exposure to TV, independent of the survey (figure 2). A large proportion of students reported $\mathrm{PC} \geq 5$ hours/day and $\mathrm{VG} \leq 2$ hours/day on weekdays, whereas on the weekend a considerable proportion of students reported $\geq 5$ hours/day, mainly in 2012 (46.5\%) (Figure 2). 
Figure 2. Time of use of TV, PC and VG, on weekdays, and weekend days, stratified by year (2007 and 2012).
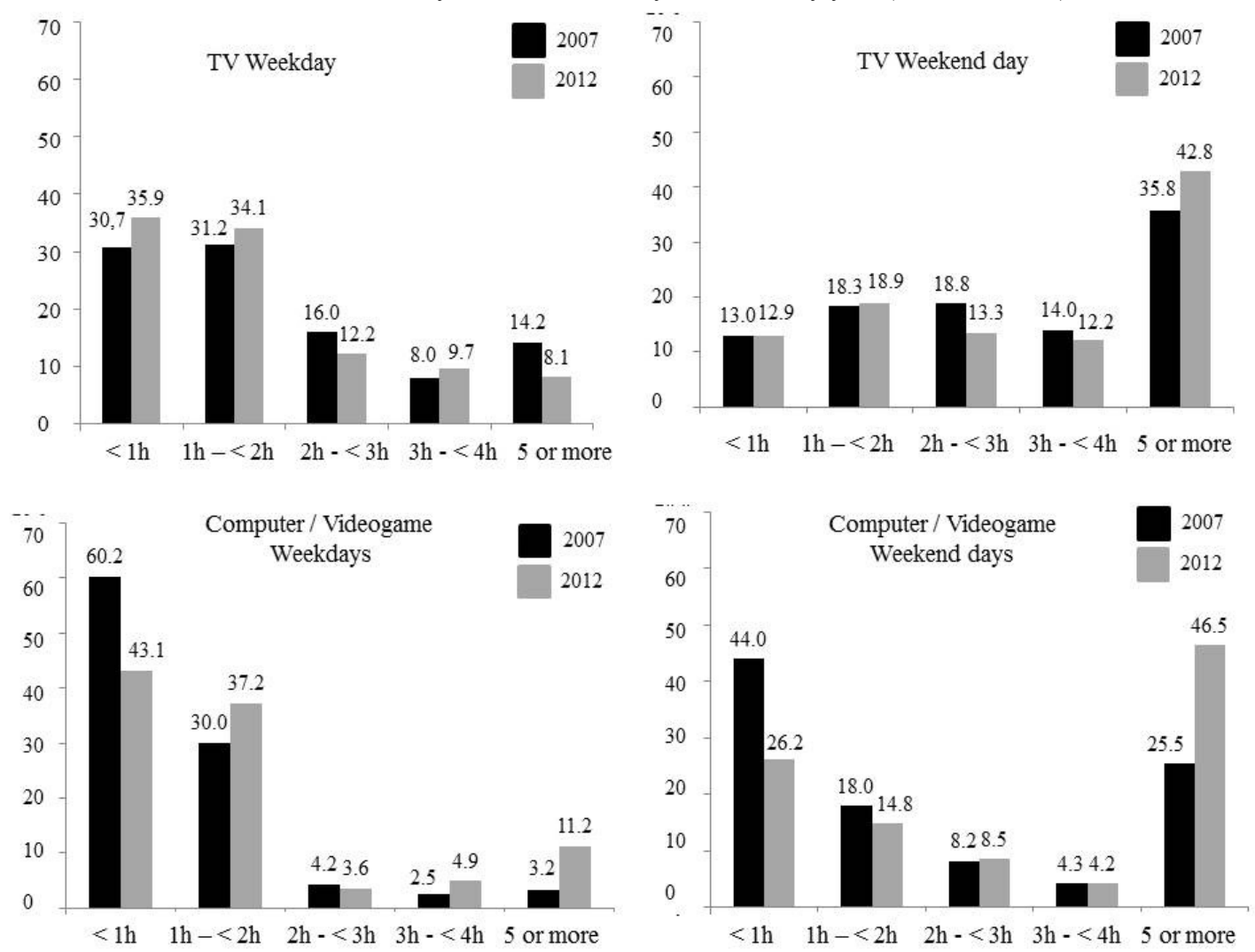

Table 3 shows the adjusted regression models to identify the factors associated with excessive exposure to the different screen-based devices. For TV, being a girl was associated with a lower chance of having $\geq 3$ hours/day of exposure, only in 2012 . For PC/VG, being a girl, physically active, and studying at night were associated with a lower chance of presenting $\geq 3$ hours/ day of exposure, whereas living in an urban area and having

a monthly household income $\geq \mathrm{R} \$ 1,001.00$ were associated with a higher chance of presenting $\geq 3$ hours/day of exposure, only in 2012. For total screen time, being physically active was associated with a lower chance of having $\geq 3$ hours/day of exposure in 2007, whereas being a girl was associated with a lower chance of presenting $\geq 3$ hours/day of exposure in 2012 .

Table 3. Adjusted regression of factors associated with TV time, computer and videogame time, and weekly screen time considering the years of 2007 and 2012 of high school students of the public school network of Caruaru, PE, Brazil.

\begin{tabular}{|c|c|c|c|c|c|c|}
\hline & \multicolumn{2}{|c|}{ TV time } & \multicolumn{2}{|c|}{ PC/VGTime } & \multicolumn{2}{|c|}{ Total Screen Time } \\
\hline & 2007 & 2012 & 2007 & 2012 & 2007 & 2012 \\
\hline $\begin{array}{l}\text { Gender } \\
\text { Boys } \\
\text { Girls }\end{array}$ & $\begin{array}{l}1 \\
0.87(0.61-1.45)\end{array}$ & $\begin{array}{l}1 \\
0.40(0.27-0.60)\end{array}$ & $\begin{array}{l}1 \\
0.75(0.42-1.35)\end{array}$ & $\begin{array}{l}1 \\
0.63(0.42-0.93)\end{array}$ & $\begin{array}{l}1 \\
0.92(0.65-1.33)\end{array}$ & $\begin{array}{l}1 \\
0.63(0.43-0.92)\end{array}$ \\
\hline $\begin{array}{l}\text { Age } \\
15-17 \text { years old } \\
18-20 \text { years old }\end{array}$ & $\begin{array}{l}1 \\
1.06(0.70-1.58)\end{array}$ & $\begin{array}{l}1 \\
0.84(0.58-1.22)\end{array}$ & $\begin{array}{l}1 \\
0.93(0.48-1.88)\end{array}$ & $\begin{array}{l}1 \\
0.78(0.41-1.18)\end{array}$ & $\begin{array}{l}1 \\
1.07(0.71-1.59)\end{array}$ & $\begin{array}{l}1 \\
0.82(0.57-1.19)\end{array}$ \\
\hline $\begin{array}{l}\text { Marital status } \\
\text { Single } \\
\text { Other }\end{array}$ & $\begin{array}{l}1 \\
1.26(0.78-2.02)\end{array}$ & $\begin{array}{l}1 \\
0.72(0.41-1.26)\end{array}$ & $\begin{array}{l}1 \\
1.64(0.89-2.80)\end{array}$ & $\begin{array}{l}1 \\
1.13(0.70-1.83)\end{array}$ & $\begin{array}{l}1 \\
0.98(0.60-1.62)\end{array}$ & $\begin{array}{l}1 \\
0.91(0.58-1.43)\end{array}$ \\
\hline $\begin{array}{l}\text { Place of residence } \\
\text { Rural } \\
\text { Urban }\end{array}$ & $\begin{array}{l}1 \\
1.25(0.69-2.25)\end{array}$ & $\begin{array}{l}1 \\
1.61(0.85-3.06)\end{array}$ & $\begin{array}{l}1 \\
1.52(0.80-2.88)\end{array}$ & $\begin{array}{l}1 \\
5.03(2.77-7.41)\end{array}$ & $\begin{array}{l}1 \\
0.66(0.36-1.22)\end{array}$ & $\begin{array}{l}1 \\
1.40(0.80-2.52)\end{array}$ \\
\hline $\begin{array}{l}\text { Monthly household } \\
\text { income } \\
\text { Up to R } \$ 1.000,00 \\
\mathrm{R} \$ 1.001,00 \text { or } \\
\text { more }\end{array}$ & $1.24(0.85-1.82)$ & $1.42(0.91-2.22)$ & $\begin{array}{l}1 \\
1.40(0.87-1.90)\end{array}$ & $1.55(1.04-2.30)$ & $\begin{array}{l}1 \\
0.85(0.58-1.25)\end{array}$ & $1.26(0.86-1.84)$ \\
\hline
\end{tabular}




\begin{tabular}{|c|c|c|c|c|c|c|}
\hline & \multicolumn{2}{|c|}{ TV time } & \multicolumn{2}{|c|}{ PC/VGTime } & \multicolumn{2}{|c|}{ Total Screen Time } \\
\hline & 2007 & 2012 & 2007 & 2012 & 2007 & 2012 \\
\hline \multicolumn{7}{|c|}{ High school year } \\
\hline $1 \mathrm{st}$ & 1 & 1 & 1 & 1 & 1 & 1 \\
\hline $2^{\text {nd }}$ & $1.16(0.77-2.22)$ & $1.21(0.88-2.32)$ & $0.91(0.68-2.08)$ & $1.08(0.84-1.38)$ & $0.92(0.72-1.18)$ & $1.05(0.84-1.32)$ \\
\hline $3^{\text {rd }}$ & $1.08(0.68-2.12)$ & $1.18(0.84-2.18)$ & $0.94(0.71-2.14)$ & $1.11(0.91-1.41)$ & $0.81(0.53-1.15)$ & $1.09(0.89-1.41)$ \\
\hline \multicolumn{7}{|c|}{ Study Shift } \\
\hline Morning & 1 & 1 & 1 & 1 & 1 & 1 \\
\hline At night & $0.93(0.63-1.37)$ & $0.90(0.59-1.17)$ & $0.91(0.49-1.73)$ & $1.64(0.89-2.80)$ & $0.78(0.41-1.18)$ & $0.61(0.32-1.04)$ \\
\hline \multicolumn{7}{|c|}{ Physical activity } \\
\hline Inactive & 1 & 1 & 1 & 1 & 1 & 1 \\
\hline Active & $0.98(0.71-1.42)$ & $0.71(0.48-1.08)$ & $0.81(0.40-1.09)$ & $0.47(0.30-0.74)$ & $0.67(0.46-0.96)$ & $0.88(0.61-1.24)$ \\
\hline
\end{tabular}

$\mathrm{TV}=$ Television $; \mathrm{PC}=$ Computer; $\mathrm{VG}=$ Videogame

\section{Discussion}

The main findings of the current study were fourfold: i) the average time of exposure to TV decreased on weekdays and weekly, but no change was observed in the proportion of exposure to $\geq 3$ hours/day of TV from 2007 to 2012 ; ii) the average time and proportion of excessive exposure to $\mathrm{PC} / \mathrm{VG}$ increased from 2007 to 2012 on both week and weekend days; iii) despite an increase in average total screen time, the prevalence of excessive exposure to total screen time did not change significantly from 2007 to 2012; and iv) being physically active was a protection factor for excessive exposure to total screen time (2007). In 2012, girls presented less risk for all screen-based devices and total screen time. Studying at night and being physically active were protective factors, while residing in the urban area and having higher family income were risk factors to excessive exposure to $\mathrm{PC} / \mathrm{VG}$ time.

The lack of changes in the proportion of students with excessive exposure to TV ( $\geq 3$ hours/day) contrasts with the results from previous studies conducted between 2001-2011 in the state of Santa Catarina, Brazil ${ }^{8-9}$. Said study showed a reduction in prevalence of this behavior. The period of data collection and the region could explain, at least in part, these differences. Specifically in Brazil, the early years after 2000 were marked by changes in social and economic conditions; a combination of unemployment reduction, progressive increases in the minimum wage, and expansion of cash transfer programs ${ }^{10}$, which directly influenced the access to and use of electronic devices ${ }^{11}$. On the one hand, there was an increase in access to new technologies such as computers, tablets, cell phones, smartphones, and the internet, while on the other hand, the timing of access in regions, capitals, and cities with greater economic development was earlier when compared to regions, rural cities, and areas with less economic development ${ }^{11}$.

The reduction in TV use could be linked to the lack of interactivity related to this device (e.g., TV does not have social networks, which is of interest to young individuals). In fact, adolescents are the largest users of other electronic devices such as PCs and VGs (PNAD), which provide greater freedom to seek information and entertainment, especially with access to the internet.

Similar to the results from previous national and international studies $^{8,9,13-15}$, we demonstrated that there was an increase in the proportion of students with excessive exposure to PC/VG. Interestingly, these trends have been observed even with different cut-off points, which reinforce the growing use of these devices. This phenomenon could be explained by the recent access to different electronic media and technological evolution, which enables different patterns of interactivity.

The magnitude of change in the proportion of exposure to PC/VG was higher than that observed in a previous study $(135 \%$ vs. $60 \%)^{8}$, which again might be explained by the different collection data periods. Accordingly, a previous study published by the National Household Survey indicated an increase in the number of TVs, PCs, and internet access in Brazilian households ${ }^{10}$, however this increase was more accelerated in developed regions (e.g., southern) compared to less developed regions (e.g., northeastern) in Brazil. Therefore, it is reasonable to speculate that access to PCs and VGs was still increasing during the data collection period of the current study, while already stable in other regions.

It should be mentioned that other studies published in developing countries present different results. A secular trend study ${ }^{13}$, conducted in the United States, considering 2001 - 2012, observed a decrease in TV time in preschoolers (19\%) and schoolchildren ( $6 \%$, not significant). This decrease could be explained by the early use of devices such as PCs, smartphones, and tablets ${ }^{13}$. Two surveys (2001-2009), with American teenagers between 2001 and 2009, considering TV, PC, and VG time, noted that overall TV time declined both on weekdays and weekends ${ }^{14}$. The use of PCs and VGs was analyzed only in the period from 2005 to 2009, during which period an average of 2 hours/day for these devices was observed, but which did not present significant changes in the time of use $\mathrm{e}^{14}$. A Spanish study concluded that adolescents spend an average of 3 hours/ day watching TV, increasing their use during the weekend ${ }^{15}$. In the same way, the time of exposure to PCs and VGs increased due to connection to the internet, obtaining a mean use of 4.5 $\mathrm{h} /$ day, indicating a discreet increase on the weekend ${ }^{15}$.

On the other hand, national studies presented similar results to the present study. Some studies in Brazil that evaluated only the habit of watching TV confirmed a decrease ${ }^{16-18}$, and Silva et al. ${ }^{8}$ and Lopes et al. ${ }^{9}$ add information that agrees with our findings, also showing a decrease in the use of TV and an increase in the use of PCs and VGs. Although these findings are opposite in some points, they approximate the findings of the present study, 
noting that there are clear cultural differences, as is the case with states in Brazil and developed countries; thus highlighting that these patterns may have some similarity, but are not equal. In addition to cultural differences, it is also necessary to take into account the differences in methods used to assess exposure to these devices in each study, as demonstrated by Oliveira et al. ${ }^{19}$, in which methodological differences between the findings were identified and were shown to have influenced the results. However, no mention was made of the function and modes of use of the devices in relation to the possibilities of use of PCs, TVs, smartphones, and VGs. For example, TV does not have social networks, which is what interests young people. Smartphones have all the functions and facilities to allow users to browse the internet, so they can be used both as a VG and to watch videos, among other uses. The decrease in TV viewing time and increase in PC and VG use are confirmed in the majority of studies cited above, which may indicate a substitution in entertainment patterns and electronic devices among adolescents, pointing out that this has been happening since Brazil began to have a more stable economy and, consequently, an improvement in the purchasing power of the population. As previously reported in other studies, the present study found changes in relation to the amount of total screen time, TV time, and PC and VG time, both on week and weekend days.

Another issue related to the different patterns of use of screen devices are the socioeconomic differences in Brazil, which caused a technological advance, facilitating the use of the internet, tablets, PCs, and smartphones ${ }^{11}$. In the present study, the economic factor was observed to be associated with exposure to PC/VG only in 2012, not in 2007. The PNAD report indicated that between 2004 and 2014 there was a significant increase in internet access from a computer (6.3 million to 25.7 million households), mainly in urban areas, which increased as household incomes increased ${ }^{11}$. The authors agree with Silva and colleagues ${ }^{8}$ who argued that regarding the use of $\mathrm{PC} / \mathrm{VG}$, patterns of income were determinants, and this might be due to the cost of purchasing these devices. In addition, the quality and type of internet connection when comparing regions and urban areas is a factor associated with this difference.

Previous studies in Brazil have reported differences in sedentary behavior between genders ${ }^{20-22}$, while others have not identified significant differences ${ }^{23-24}$. Moreover, the few studies in Brazil that examined the use of other types of media have yielded mixed results. Since the use of media is becoming more central to the daily lives of adolescents, understanding the pattern of use and interactivity tend to become more complex. Ohannessian $(2009)^{25}$ argued that this is the result of the interaction between characteristics of the individual and context.

It is well recognized that physical activity and sedentary behavior may coexist, and most importantly, they might interact ${ }^{11}$. The results of the current study corroborate this assumption by showing that being physically active was considered a protection factor for exposure to TV. Accordingly, a recent meta-analysis of prospective studies, with more than one million individuals, demonstrated that achieving an amount of moderate physical activity (i.e., about 60-75 min per day) appears to eliminate the increased mortality risk related to increased sitting time and attenuated the risk associated to exposure to $\mathrm{TV}^{26}$.

A strong point of the present study is that it is one of the few studies to evaluate the specific domains of screen time separately. Therefore, changes were observed when comparing the two periods, both with weighted estimates of screen time and evaluations performed for each screen device. Moreover, the sample calculation was performed using parameters to obtain greater precision in the estimates of the studied variables, obtaining results with certain accuracy. Conversely, some limitations must be considered. Several studies have used selfreported measures for the amount of time of use for all devices, which would be a limiting point of our study, as this measure has an estimated value. Another limitation of the study was to consider only the TV, PC, and VG as screen use, since exploratory studies have been evaluating the time of use of tablets and smartphones. These screen devices are also important in the current context, yet access to these new technologies at the time was not common. Another limitation of our study was it joined the two types of screen time (PC and VG), since, undoubtedly, there is information that is lost due to this weighting, making it difficult to establish which of the two apparatuses has greater predominance among adolescents.

\section{Conclusion}

The results indicate that there were significant changes in the use of screen devices, after half a decade, considering that the use of TV among adolescents presented a significant decrease and the time using a PC and VG presented a significant increase, compensating for the decrease in TV use. However, the time that adolescents are exposed to this type of device is still very high. This is due to the technological changes during that period of time and the economic stability that directly influences these types of human behaviors. Further research that considers all screen devices that are currently being used by different populations due to the accelerated technological evolution is suggested, in addition to research with approaches that allow for clarification of the cause-effect between variables related to screen time, as is the case of longitudinal studies.

\section{References}

1. Flynn MA, McNeil DA, Maloff B, Mutasingwa D, Wu M, Ford $\mathrm{C}$, et al. Reducing obesity and related chronic disease risk in children and youth: a synthesis of evidence with 'best practice' recommendations. Obesity reviews : an official journal of the International Association for the Study of Obesity. 2006; 7 (Suppl 1):7-66.

2. Tremblay MS, LeBlanc AG, Kho ME, Saunders TJ, Larouche R, Colley RC, et al. Systematic review of sedentary behaviour and health indicators in school-aged children and youth. Int J Behav Nutr Phys Act. 2011;8(98):1-22.

3. World Health Organization. Global Recommendations on physical activity for health. Cataloguing-in-Publication Data 
Global Library. Geneve.: Available from: <http://www.who.int/ dietphysicalactivity/publications/9789241599979/en/>. 2010.

4. Centers for Disease Control and Prevention. Improving the Health of Adolescents \& Young Adults: A Guide for States and Communities. Atlanta, GA. 2004: Available from: http://nahic. ucsf.edu/wp-content/uploads/2011/11/Complete-2010Guide.pdf.

5. Lowry R, Lee SM, Fulton JE, Kann L. Healthy people 2010 objectives for physical activity, physical education, and television viewing among adolescents: national trends from the Youth Risk Behavior Surveillance System, 1999-2007. J Phys Act Health. 2009;6(Suppl 1):S36-45.

6. Nelson MC, Neumark-Stzainer D, Hannan PJ, Sirard JR, Story M. Longitudinal and secular trends in physical activity and sedentary behavior during adolescence. Pediatrics. 2006;118(6):e1627-34.

7. Samdal O, Tynjala J, Roberts C, Sallis JF, Villberg J, Wold B. Trends in vigorous physical activity and TV watching of adolescents from 1986 to 2002 in seven European Countries. Eur J Public Health. 2007;17(3):242-8.

8. Instituto Brasileiro de Geografia e Estatística. Síntese de indicadores sociais: uma análise das condições de vida da população Brasileira. Brasil: IBGE; 2016. Available from: http:/ http://biblioteca.ibge.gov.br/visualizacao/livros/liv98965.pdf [Accessed 18th June 2017]

9. Silva KS, da Silva Lopes A, Dumith SC, Garcia LM, Bezerra J, Nahas MV. Changes in television viewing and computers/ videogames use among high school students in Southern Brazil between 2001 and 2011. Int J Public Health. 2014;59(1):77-86.

10. Lopes AS, Silva KS, Barbosa Filho VC, Bezerra J, de Oliveira ES, Nahas MV. Trends in screen time on week and weekend days in a representative sample of Southern Brazil students. J Public Health (Oxf). 2014;36(4):608-14.

11. Tassitano RM, Dumith SC, Chica DAG, Tenório MCM. Aggregation of the four main risk factors to non-communicable diseases among adolescents. RevBrasEpidemiol. 2014;17(2):465-78.

12. Loprinzi PD; Davis RE. Secular trends in parent $\square$ reported television viewing among children in the United States, 20012012. Child: care, health anddevelopment. 2016;42(2): 288-291.

13. Iannotti RJ \& Wang J. (2013). Trends in physical activity, sedentary behavior, diet, and BMI among US adolescents, 2001-2009. Pediatrics. 2013;132(4): 606-614.

14. Bercedo SA, Redondo FC, Pelayo AR. Consumo de los medios de comunicación en la adolescencia. An Pediatr (Barc). 2005; 63(6): 516-525.

15. Mielke GI, Hallal PC, Malta DC, Lee IM. Time trends of physical activity and television viewing time in Brazil: 2006-2012. Int J Behav Nutr Phys Act. 2014;11(101).

16. Tassitano R, Mielke G, Carvalho W, Oliveira M, Malta D. Tendência temporal de indicadores da prática de atividade física e comportamento sedentário nas capitais da Região Nordeste do Brasil: 2006-2013. Rev Bras Ativ Fís Saúde. 2015: 20(2);152-64.

17. Rech C, Reis R, Hino A, De Sá G, Stopa S, \& Malta D. Tendências temporais de atividade física e comportamento sedentário nas capitais da Região Sul do Brasil: 2006-2013. Rev Bras Ativ Fís Saúde. 2015;20(1):47-56.
18. Silva OS, Soares AHG, Silva BRVS, Tassitano RM. Prevalência do tempo de tela como indicador do comportamento sedentário em adolescentes brasileiros: uma revisão sistemática. Motricidade. 2016;12(s2):155-64.

19. Farias Júnior JC, Lopes ADS, Mota J, Hallal PC. Physical activity practice and associated factors in adolescents in Northeastern Brazil. Rev Saúde Públ. 2012;46(3):505-515.

20 Dias PJ, Domingos, IP, Ferreira MG, Muraro AP, Sichieri R, Gonçalves-Silva RMV. (2014). Prevalência e fatores associados aos comportamentos sedentários em adolescentes. Rev Saúde Públ. 2014; 48(2):266-274.

21 Tenório MCM, Barros MVG, Tassitano RM, Bezerra J, Tenório J M, Hallal PC. Atividade física e comportamento sedentário em adolescentes estudantes do ensino médio. Rev bras epidemiol. 2010;13(1):105-17.

22 Martins MO, Cavalcante VLF, Holanda GS, Oliveira CG, Maia FES, Meneses Júnior J R, et al. Associação entre comportamento sedentário e fatores psicossociais e ambientais em adolescentes da região nordeste do Brasil. Rev Bras Ativ Fís Saúde. 2012;17(2):143-150.

23. Silva KS, Barbosa Filho VC, Del Duca GF, Peres MA, Mota J, Lopes, AS et al. Gender differences in the clustering patterns of risk behaviours associated with non-communicable diseases in Brazilian adolescents. Prev Med. 2014;65:77-81.

24. Silva KS, Lopes AS, Dumith SC, Garcia LMT, Bezerra J, Nahas MV. Changes in television viewing and computers/videogames use among high school students in Southern Brazil between 2001 and 2011. IntJ Public Health. 2014;59(1):77-86.

25. Ohannessian CM. Media use and adolescent psychological adjustment: An examination of gender differences. J Child Fam Stud. 2008;18(5):582-593.

26. Ekelund U, Steene-Johannessen J, Brown WJ, Fagerland MW, Owen N, Powell KE, et al.. Does physical activity attenuate, or even eliminate, the detrimental association of sitting time with mortality? A harmonised meta-analysis of data from more than 1 million men and women. The Lancet. 2016;388(10051):1302-1310.

\section{Corresponding author}

*Rafael Miranda Tassitano

Universidade Federal Rural de Pernambuco, Physical Education, Rua Dom Manoel de Medeiros S/N Dois Irmãos. Recife, Brazil

Email: rafael_tassitano@hotmail.com

Manuscript received on July 30, 2017

Manuscript accepted on October 10, 2017

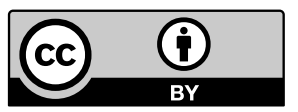

Motriz. The Journal of Physical Education. UNESP. Rio Claro, SP, Brazil - eISSN: 1980-6574 - under a license Creative Commons - Version 3.0 